Article

\title{
Polysaccharide Fraction Extracted from Endophytic Fungus Trichoderma atroviride D16 Has an Influence on the Proteomics Profile of the Salvia miltiorrhiza Hairy Roots
}

\author{
Wei Peng ${ }^{1,2, \dagger}$, Qian-liang Ming ${ }^{3,+}$, Xin Zhai ${ }^{1}$, Qing Zhang ${ }^{2}$, Khalid Rahman ${ }^{4}$, Si-jia Wu ${ }^{1}$, \\ Lu-ping Qin ${ }^{5, *}$ and Ting Han ${ }^{1, *} * \mathbb{C}$ \\ 1 Department of Pharmacognosy, School of Pharmacy, Second Military Medical University, 325 Guohe Road, \\ Shanghai 200433, China \\ 2 School of Pharmacy, Chengdu University of Traditional Chinese Medicine, No.1166 Liutai Avenue, \\ Chengdu 611137, China \\ 3 Department of Pharmacognosy, School of Pharmacy, Army Medical University, 30 Gaotanyan Street, \\ Chongqing 400038, China \\ 4 Faculty of Science, School of Pharmacy and Biomolecular Sciences, Liverpool John Moores University, \\ Byrom Street, Liverpool L3 3AF, UK \\ 5 School of Pharmacy, Zhejiang Chinese Medical University, Hangzhou 310053, China \\ * Correspondence: lpqin@zcmu.edu.cn (L.-p.Q.); hanting@smmu.edu.cn or than927@163.com (T.H.); \\ Tel.: +86-21-81871306 (T.H.) \\ + Authors contributed equally to this manuscript.
}

Received: 29 July 2019; Accepted: 20 August 2019; Published: 26 August 2019

\begin{abstract}
Trichoderma atroviride develops a symbiont relationship with Salvia miltiorrhiza and this association involves a number of signaling pathways and proteomic responses between both partners. In our previous study, we have reported that polysaccharide fraction (PSF) of T. atroviride could promote tanshinones accumulation in S. miltiorrhiza hairy roots. Consequently, the present data elucidates the broad proteomics changes under treatment of PSF. Furthermore, we reported several previously undescribed and unexpected responses, containing gene expression patterns consistent with biochemical stresses and metabolic patterns inside the host. In summary, the PSF-induced tanshinones accumulation in S. miltiorrhiza hairy roots may be closely related to $\mathrm{Ca}^{2+}$ triggering, peroxide reaction, protein phosphorylation, and jasmonic acid (JA) signal transduction, leading to an increase in leucine-rich repeat (LRR) protein synthesis. This results in the changes in basic metabolic flux of sugars, amino acids, and protein synthesis, along with signal defense reactions. The results reported here increase our understanding of the interaction between T. atroviride and S. miltiorrhiza and specifically confirm the proteomic responses underlying the activities of PSF.
\end{abstract}

Keywords: polysaccharide fraction; Trichoderma atroviride; Salvia miltiorrhiza; proteomics; tanshinones

\section{Introduction}

Salvia miltiorrhiza is a Chinese traditional medical herb widely used for preventing and treating disorders of liver, vascular, menstrual, and blood circulation systems. Diterpenoid pigments are the main bioactive constituents of $S$. miltiorrhiza roots, and exert anti-inflammatory properties via significant inhibition of production of NO, IL- $1 \beta$, and TNF- $\alpha[1,2]$. In particular, tanshinones, the predominant active constituents in the roots of $S$. miltiorrhiza, possess various promising bioactivities, such as anti-inflammation, anticoagulation, and liver protection, etc. [2,3]. However, the current production of tanshinones is not meeting the current medicinal market needs. Hairy root can yield a 
great number of secondary metabolites due to its fast growth and biochemical stability. As a typical material in plant science research, $S$. miltiorrhiza hairy roots were investigated for increased production of diterpenoid constituents for pharmaceutical usages.

Endophytic fungi, as non-harm microbes, can form long-term beneficial relationships with the host plant and could also produce some active natural secondary metabolites mainly including small molecules, which can be explained by the hypothesis of balance antagonism. Endophytic fungi is distinctive from normal chemical elicitors with the same effects on secondary metabolites accumulation as biotic inducer as reported [4-6]. Endophytic fungi can break through the first defense line of plants' microbe-associated molecule patterns (MAMPs) [7], and the cell wall is the primary structure of plants that comes in contact with its microbes. Chitin has been identified and studied as a well-known elicitor in pathogens or beneficial fungi; and great importance is also attached to $\beta$-glucan in microbe-plant relationship research. As previously reported, polysaccharides are another type of elicitors in the cell walls of fungus and bacterium to induce the resistance of plants, as well as promoting the accumulation of secondary metabolites [7,8]. Consequently, chitins, $\beta$-glutan, and polysaccharides are the components of the fungal cell wall [9]; although Chen et al. [10] have implicated that mannose can be listed as a new elicitor which is different from other known elicitors, thus broadening our knowledge and perception of other components of the fungi cell wall as elicitors [11]. In our previous study, we found that the Trichoderma atroviride, an endopyhtic fungus isolated from S. miltiorrhiza, was able to produce tanshinone I and tanshinone IIA. In addition, we also reported that the extracts of mycelium (EM) and the polysaccharide fraction (PSF) of T. atroviride have more efficient influences than live fungus, especially the PSF. Therefore, PSF may be the key active constituent as elicitor of T. atroviride in eliciting tanshinones accumulation [6].

Though the balance antagonism hypothesis can explain the interaction mechanism between endophytic fungi and host plant, the molecular signaling transduction process of plants in response to endophytic fungi is still unclear [12]. Due to post-translational events and modifications, proteomics is more specific compared to mRNA when investigating signaling and metabolic processes in plants $[13,14]$. Currently, the isobaric tags for relative and absolute quantitation (iTRAQ) have developed into significant technology which can analyze, quantify, and compare protein levels linked with liquid chromatography-quadrupole mass spectrometry (LC-MS/MS), providing greater efficiency and accuracy when compared with gel-based techniques. Some reports of novel differently-expressed types of proteins in the interaction between host plant and endophytic fungi do exist $[15,16]$. For example, the endophytic fungus Gilmaniella sp. AL12 can induce Atractylodes lancea to yield volatile oils through G protein-mediated signal transduction and the mannose-binding lectin pathway according to proteome analysis [17]. The aim of the present study was to investigate the influences of PSF from T. atroviride D16 (D16 PSF) on the proteomics profile of the S. miltiorrhiza hairy roots and its possible mechanisms based on iTRAQ strategy.

\section{Materials and Methods}

\subsection{The Culture and Treatment of Hairy Root}

Simple hairy roots were separated into different $250 \mathrm{~mL}$ conical flasks equipped with $100 \mathrm{~mL}$ half-strength B5 liquid medium at $25{ }^{\circ} \mathrm{C}, 135 \mathrm{rpm}$ in the dark. Every Erlenmeyer flask was loaded with $0.1 \mathrm{~g}$ hairy root and was cultured for 3 weeks and the liquid medium was changed weekly. The blank and the treatment group were cultured in half B5 liquid medium, except that the treatment group also contained $60 \mathrm{mg} / \mathrm{L}$ PSF. The hairy root samples were taken out for further experiments on the third and sixth days after treatment commenced.

The samples were handled with liquid nitrogen to remove the moisture and then deposited in $-80{ }^{\circ} \mathrm{C}$ refrigerator. The blank group samples taken on day 3 were numbered A1 and A2, while treatment group samples were numbered B1 and B2. Similarly, the blank group samples taken on day 6 
were numbered C1 and C2, while treatment group samples were numbered D1 and D2. However, hairy root samples were disposed by the same method on the twelfth day after treatment for RNA extraction.

\subsection{The Preparation of PSF}

The hyphae of T. atroviride D16 was transferred into the newly-made Potato Dextrose Agar (PDA) medium for 4 days and then moved into $250 \mathrm{~mL}$ conical flasks containing $100 \mathrm{~mL}$ half B5 liquid medium and cultured for 3 days. Finally, the cultured D16 was added into 5 L conical flask for amplified culturing between 7 to 10 days. Subsequently, the mycelia were collected with vacuum suction filtration, washed three times with distilled water and homogenized by placing in a blender for $10 \mathrm{~min}$, followed by addition of three volumes of distilled water equivalent to the wet weight of mycelia. The water solution of mycelia was then heated to a temperature of $121^{\circ} \mathrm{C}$ under high pressure for $60 \mathrm{~min}$ and was filtered as fungal elicitor. The filtrate was decompressed and concentrated to an appropriate volume at $75^{\circ} \mathrm{C}$ and mixed with 4 times volume of $95 \%$ ethanol for 2 days at room temperature. After lyophilization, the precipitate was further subjected to deproteinization with Sevag reagent (chloroform:n-butanol, 4:1, v/v), and small molecule impurities were removed as well as proteins less than $2000 \mathrm{kDa}$. Thereafter, the solution was freeze-dried under vacuum into powder as PSF.

\subsection{Monosaccharides Composition of PSF}

A total of $5.00 \mathrm{mg}$ D16 PSF was hydrolyzed with trifluoroacetic acid (TFA, $2 \mathrm{M}$ ) for $2 \mathrm{~h}$ at $120{ }^{\circ} \mathrm{C}$ hermetically, the TFA was then evaporated under vacuum, and the residue was subsequently washed three times with methanol. The residue was then mixed with $30 \mathrm{mg} \mathrm{NaBH} 4$ and $1 \mathrm{~mL} \mathrm{H}_{2} \mathrm{O}$ and left overnight for reduction followed by the addition of methanol and acetic acid at a ratio of 5:1, the solvent was evaporated under reduced pressure, followed by the addition and evaporation of methanol three times. The sample was then left to dry at $105{ }^{\circ} \mathrm{C}$ for $10 \mathrm{~min}$ followed by acetylation of the sample by the addition of $3 \mathrm{~mL}$ acetic anhydride $\left(\mathrm{AC}_{2} \mathrm{O}\right)$, for $60 \mathrm{~min}$ at $105^{\circ} \mathrm{C}$, after which the reaction was terminated by the addition of $1 \mathrm{~mL}$ water followed by vortex mixing. The acetylation products were extracted with $2 \mathrm{~mL}$ chloroform, which was then dried by the addition of anhydrous sodium sulfate prior to GC-MS analysis. The standard products (including rhamnose, arabinose, xylose, fructose, mannose, glucose, and galactose, which were purchased from the National Institute for Food and Drug Control, Beijing, China) were subjected to the same procedure as the sample without hydrolyzation.

GC-MS analysis conditions: The size of TR-5MS (Thermo) chromatographic column was $60 \mathrm{~m} \times 0.25 \mathrm{~mm} \times 0.25 \mathrm{~mm}$; initial conditions: The programmed temperature was 140 to $198{ }^{\circ} \mathrm{C}$ at $2{ }^{\circ} \mathrm{C} / \mathrm{min}$ and kept for $4 \mathrm{~min}$. The temperature was then increased to $214^{\circ} \mathrm{C}$ at $4{ }^{\circ} \mathrm{C} / \mathrm{min}$ and $217{ }^{\circ} \mathrm{C}$ at $1{ }^{\circ} \mathrm{C} / \mathrm{min}$ for $4 \mathrm{~min}$. Finally, the temperature was raised to $250^{\circ} \mathrm{C}$ at $3^{\circ} \mathrm{C} / \mathrm{min}$ for $5 \mathrm{~min}$; injection port temperature was $250^{\circ} \mathrm{C}$; the carrier gas was He; the flow rate was $1 \mathrm{~mL} / \mathrm{min}$; ion source $250^{\circ} \mathrm{C}$; $m / z=40-500 ; \mathrm{EI}=70 \mathrm{ev}$.

\subsection{HPLC Analyses}

The hairy roots were dried at $50{ }^{\circ} \mathrm{C}$ in an oven until a constant weight was obtained and then grounded into powder form. The powder was then extracted with chromatographic pure methanol for $60 \mathrm{~min}$ under sonication. Next, the methanol extract was applied to the high-performance liquid chromatography (HPLC) system-Agilent-1100-for analysis. The Agilent-1100 was carried out with a $\mathrm{H}_{2} \mathrm{O}$ (containing $\left.0.5 \% \mathrm{HCOOH}\right)(\mathrm{A})$ /acetonitrile (B) gradient by a ZORBAX SB-C ${ }_{18}$ chromatographic column $(250 \times 4.6 \mathrm{~mm}, 5 \mu \mathrm{m})$ at $30{ }^{\circ} \mathrm{C}$ [6]. The reference standards of dihydrotanshinone I (DT-I), tanshinone I (T-I), cryptotanshinone (CT), and tanshinone IIA (T-IIA) were purchased from the Chengdu Mansite Pharmaceutical Co. Ltd. (Chengdu, China). In addition, dihydrotanshinone I $(0.0025,0.0050,0.0100,0.0200$, and $0.0400 \mathrm{mg} / \mathrm{mL})$, tanshinone I $(0.002,0.004,0.006,0.008$, and $0.010 \mathrm{mg} / \mathrm{mL})$, cryptotanshinone $(0.001,0.005,0.010,0.025,0.050$, and $0.100 \mathrm{mg} / \mathrm{mL})$, and tanshinone IIA $(0.0005,0.001,0.002,0.004,0.006$, and $0.008 \mathrm{mg} / \mathrm{mL})$ were used to prepare the standards curves. 
The methanol extract of hairy roots was analyzed and the peaks identified and contrasted in comparison with the available standards.

\subsection{RNA Isolation and Real-Time Quantitative PCR Analysis}

TRIzol reagent (Invitrogen Co., Carlsbad, CA, USA) was used to extract the total RNA of hairy root and $1 \mu \mathrm{L}$ RNA was diluted to $100 \mu \mathrm{L}$ with RNase $d_{d H_{2}} \mathrm{O}$. According to the RNA concentration ratio of 260 and $280 \mathrm{~nm}$ UV absorbance value, OD260/280 should be between 1.9 to 2.1 and the total RNA concentration was calculated according to the formula total RNA $(\mu \mathrm{g} / \mathrm{mL})=\mathrm{OD} 260 \times 100$ (dilution multiple) $\times 40 \mu \mathrm{g} / \mathrm{mL}$. The reverse transcription reaction was conducted at $37{ }^{\circ} \mathrm{C}$ for $15 \mathrm{~min}, 85{ }^{\circ} \mathrm{C}$ for $5 \mathrm{~s}$ termination reaction at ABI 9700 PCR. Finally, $90 \mu \mathrm{L}$ RNase-free $\mathrm{ddH}_{2} \mathrm{O}$ was added to $100 \mu \mathrm{L}$ for storing at $-20{ }^{\circ} \mathrm{C}$ for Real-time PCR. Primers with the following sequences, LRRK F (5'-TGTGGTAGCTTTGTGGGGTT-3') and LRRK R (5'-CAGACCGGAGATTGAGTCCG-3'), LRRK-PEPR2 F (5'-TGTGGTAGCTTTGTGGGGTTT-3') and LRRK-PEPR2 R (5'-GCCAGACCGGAGATTGAGTC-3'), Nucleoporin F (5'-GTCAAAACCTGCAACCACCT-3') and Nucleoporin R (5'-AGAATGCTGGAGAAATGCCG-3'), probable cation-transporting ATPase F (5'-TGTCCCCATGAATTAGAACTGGT-3') and probable cation-transporting ATPase R (5'-TGGCGACTTTTGCAGTCAAC-3'), primers identifying the Smactin gene, Smactin F (5'-ATGATAACTCGACGGATCGC-3') and Smactin R (5'-CTTGGATGTGGTAGCCGTTT-3'), were used as a reference gene to normalize cDNA loading. The real-time PCR amplification was performed in a 384-well plate Roche LC480 thermocycler (Roche Diagnostic Basel, Switzerland) with Super Real PreMix kit (TIANGEN, Beijing, China). Each reaction contained a mixture of $1 \mu \mathrm{L}$ of diluted cDNA, $0.2 \mu \mathrm{L}$ of forward primer $(10 \mu \mathrm{M}), 0.2 \mu \mathrm{L}$ of reverse primer $(10 \mu \mathrm{M}), 5 \mu \mathrm{L}$ of SYBR Green PCR Master Mix (TIANGEN, Beijing, China), and $3.6 \mu \mathrm{L}$ of RNase-free $\mathrm{H}_{2} \mathrm{O}$. The reaction mixture was incubated for $15 \mathrm{~min}$ at $95^{\circ} \mathrm{C}$, and for 40 cycles of $10 \mathrm{~s}$ at $95^{\circ} \mathrm{C}$ and $30 \mathrm{~s}$ at $60^{\circ} \mathrm{C}$. The relative gene expression was quantified using the comparative CT method.

\subsection{Protein Extraction of Salvia Miltorrhiza Hariy Root}

A total of $0.5000 \mathrm{~g}$ of S. miltiorrhiza hairy root sample was grounded into powder in liquid nitrogen and transferred into $10 \%$ trichloroacetic acid and precooling acetone solution containing $65 \mathrm{mM}$ Dithiothreitol (DTT). Followed precipitation at $-20^{\circ} \mathrm{C}$ for $6 \mathrm{~h}$, the sample was centrifuged at $10,000 \mathrm{rpm}$, at $4{ }^{\circ} \mathrm{C}$ for $45 \mathrm{~min}$, and the sediment was re-suspended by the addition of $\mathrm{PH}$ standard reagent (STD buffer) according to the volume ratio of 10:1. The sample was then vortexed and blended and placed in a boiling water bath for $5 \mathrm{~min}$ and then subjected to ultrasound 10 times (ultrasound for $10 \mathrm{~s}$, interval for $15 \mathrm{~s}$ ). Finally, the sample was heated in a water bath for $5 \mathrm{~min}$ and subjected to centrifuging for $15 \mathrm{~min}$ at 10,000 rpm. The supernatant containing the total protein extract of $S$. miltiorrhiza hairy root was then stored at $-80^{\circ} \mathrm{C}$ until assayed for protein content by the bicinchonininc acid (BCA) and Bradford method.

\subsection{The Mass Spectrum Analysis of Protein}

The protein samples were enzymolyzed and the peptides solution was qualified by measuring at OD280. The sample were then analyzed by LC-MS preliminarily and performed on AKTA Purifier 100 (GE Healthcare, Chicago, IL, USA) for SCX classification via strong cation chromatographic column. Finally, the samples were separated by the Easy nLC liquid phase system of the nanoliter velocity. Q-Exactive mass spectrometer (Thermo Finnigan, Silicon Valley, CA, USA) was used to analyze the mass spectra of the sample solution after capillary HPLC separation. The analysis time was $120 \mathrm{~min}$, testing method was positive ion mode, and the mother ion scanning ranged from 300 to $1800 \mathrm{~m} / \mathrm{z}$. The level of mass spectrum resolution was 70,000 ( $\mathrm{m} / \mathrm{z} 200)$, AGC target was 3e6, first level of Maximum IT was $10 \mathrm{~ms}$, number of scan ranges was 1, and dynamic exclusion was $40 \mathrm{~s}$. The ion-charge ratio of peptide and the peptide fragments was collected according to the following methods: Full scan acquiring 10 secondary debris each map; secondary excitation types: heated capillary dissociation 
(HCD); separate window: $2 \mathrm{~m} / \mathrm{z}$; secondary mass spectrum resolution: 17,500 (200) m/z; microscans: 1; secondary maximum IT: $60 \mathrm{~ms}$; standard collision energy: $30 \mathrm{eV}$; under fill the wire: $0.1 \%$.

\subsection{Data Analysis}

The raw data of mass spectrometry was analyzed with software Mascot 2.2 and the identified proteins were blasted with UniProt database for the Gene Ontology (GO) classification annotation. The peak strength value of the reported ion was analyzed quantitatively with Proteome Discoverer1.4 software and the differentially expressed genes of $\mathrm{Fc}_{\mathrm{C}}$ (fold change, $\mathrm{Fc}_{\mathrm{C}}(\mathrm{B} / \mathrm{A})=\mathrm{B} / \mathrm{A}, \mathrm{Fc}(\mathrm{D} / \mathrm{C})=\mathrm{D} / \mathrm{C}$ ) were screened according to the standard of $F_{C} \geq 1.50$ or $F_{C} \leq 0.66$. The differentially expressed proteins identified in the Arabidopsis database were compared to the database (UniProt, SWISSPROT and TREMBL) by using the software BLASTP (2.2.23+) and the comparison results were extracted. These comments were corresponded to the GO number by the gene association file (gene association. Goa uniprot) and the number of the corresponding small items were counted in the three large catalogs of the biological process, cellular component, and molecular function. According to the bi-directional best hits (BBH) analysis, the corresponding number was mapped to KEGG pathway maps and the total protein of Arabidopsis was calculated by using the hyper-geometric distribution of $p$-value. The false discovery rate (FDR) was then used to correct it and z-score was calculated at the same time. The pathway of significant enrichment was the pathway of FDR is less than 0.05 and z-score $>0$. INTACT and String was used to construct differentially expressed protein interaction networks: (a) Searching INTACT to build network (http://www.ebi.ac.uk/intact/); (b) using the software String to build the network (http://string.embl.de).

All experiments, including both control and different treatments of hairy root cultures, HPLC analysis, and semi-quantitative real-time PCR, were performed in triplicate. The results are presented as their mean values and standard deviations (SD). The error bars in the figures represent the standard deviation in biological triplicates. The statistical significance of the differences in root growth and the accumulation of phenolic acids and tanshinones were analyzed by one-way analysis of variance (ANOVA) with SPSS software (version 18.0, Chicago, IL, USA), the heatmap was drawn using Excel software (version: 2010, Microsoft Co., Redmond, WA, USA), and the term significant was used to denote the differences for which $p$-value is $<0.05$. The statistical significance of differences in gene transcripts was analyzed by one-sample $t$-test.

\section{Results}

\subsection{Monosacharide Composition and Its Effects on Accumulation of Tanshinones of the D16 PSF}

D16 PSF was extracted from T. atroviride D16 and it had greatly induced the accumulation of tanshinones in S. miltiorrhiza hairy roots, as reported in the previous study [6]. To further determine the effects of hydrolytic constitutes on S. miltiorrhiza hairy root, the D16 PSF was hydrolyzed to determine its monosaccharides compositions, and the results revealed that D16 PSF was composited by mannose, glucose, and galactose at a ratio of 5:10:2 (Figure 1). The standard samples of mannose, glucose, and galactose were made into the solution with the concentration of $60 \mathrm{mg} / \mathrm{L}$, respectively, and then put into the S. miltiorrhiza hairy root culture medium in triplet for 14 days. The results showed the content of tanshinones in S. miltiorrhiza hairy root after 14 days' culture varied in the presence of PSF and the monosaccharides (Table 1). Compared with the control group, PSF (60 mg/L) stimulated the tanshinones accumulation at the greatest extent. Different components of PSF had various effects on promoting synthesis of tanshinones; however, the singular result of each D16 PSF constitute could not catch up with the influence of PSF on the accumulation of tanshinones. Under the treatment of PSF $(60 \mathrm{mg} / \mathrm{L})$, the content of dihydrotanshinone I was similar to the results at the same concentration of mannose and galactose respectively, while the equally-increased effects on tanshinone I were among the different treatments of PSF $(60 \mathrm{mg} / \mathrm{L})$, glucose, and mannose. Under the treatment of PSF $(60 \mathrm{mg} / \mathrm{L})$, the content of cryptotanshinones was 3.08-fold higher than the control group, while less increased 
effects occurred followed by the treatment of glucose. Galactose made the cryptotanshinones content decreased, while mannose had no effect on the accumulation of cryptotanshinones.

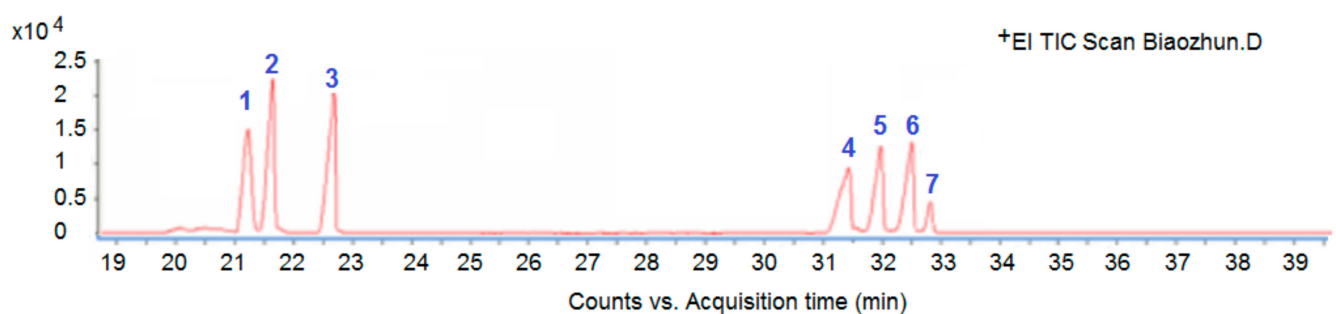

(a)

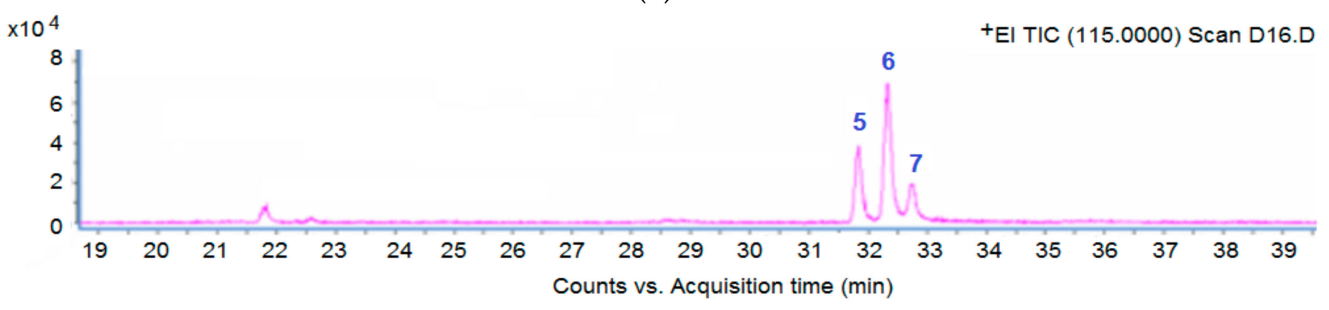

(b)

Figure 1. GC-MS analysis of D16 PSF monosaccharides components. (a) GC-MS chromatogram of monosaccharide standards; (b) GC-MS chromatogram of the D16 PSF sample. The numbers 1 to 7 represented the rhamnose, arabinose, xylose, fructose, mannose, glucose, and galactose, respectively. D16 PSF means polysaccharide fraction from T. atroviride D16.

Table 1. The effects of D16 PSF and its monosaccharide constitutes on tanshinones accumulation on the fourteenth day.

\begin{tabular}{|c|c|c|c|c|c|}
\hline Content (mg/g dw) & Control & $60 \mathrm{mg} / \mathrm{L}$ PSF & $60 \mathrm{mg} / \mathrm{L}$ Glucose & $60 \mathrm{mg} / \mathrm{L}$ Mannose & $60 \mathrm{mg} / \mathrm{L}$ Galactose \\
\hline Dihydrotanshinone I & $0.3548 \pm 0.0084$ & $1.0380 \pm 0.0455^{* * *}$ & $0.4271 \pm 0.0380$ & $1.1641 \pm 0.0133^{* * *}$ & $1.0559 \pm 0.0367^{* * *}$ \\
\hline Cryptotanshinone & $0.6421 \pm 0.0211$ & $1.9798 \pm 0.0708^{* * *}$ & $1.2007 \pm 0.0198^{* * *}$ & $0.6799 \pm 0.0138$ & $0.4209 \pm 0.0099 * * *$ \\
\hline Tanshinone I & $7.1378 \pm 0.1455$ & $11.6405 \pm 0.1581 * * *$ & $9.3103 \pm 0.1214^{* * *}$ & $10.7130 \pm 0.1163^{* * * *}$ & $7.4991 \pm 0.1744$ \\
\hline Tanshinone IIA & $0.2321 \pm 0.0022$ & $0.4713 \pm 0.0186^{* * *}$ & $0.3630 \pm 0.0054 * * *$ & $0.2811 \pm 0.0049 * *$ & $0.2639 \pm 0.0056^{*}$ \\
\hline
\end{tabular}

D16 PSF means polysaccharide fraction from T. atroviride D16. Data were expressed as mean $\pm \operatorname{SD}(n=3),{ }^{*} p<0.01$, ${ }^{* *} p<0.01,{ }^{* * *} p<0.001$, vs. control.

\subsection{Differential Proteomics of S. miltiorrhiza in Response to D16 PSF}

The differences of protein content in S. miltiorrhiza hairy roots treated with D16 PSF were studied by proteomics technique of iTRAQ. Based on the database of Arabidopsis thaliana, 3685 feature peptides (unique peptide) belonged to 1476 proteins, which were identified and analyzed for GO classification annotation. As shown in Figure 2, most of proteins can be annotated into the three ontologies of biological process, cellular component, and molecular function. In the biological process annotation, the number of proteins in the metabolic process (1162) and response to stimulus (584) was the largest, and 187 proteins were not annotated. In cellular components annotation, positioning to the cytoplasm (1036), the cell membrane (602), and the cytosol (517) account for the greatest number of proteins, while 211 proteins had not been annotated. In the molecular function annotation, a large number of proteins were divided into catalytic activity (894), nucleotide binding (507), protein binding (417), as well as metal ion binding (315) under the entry and 146 proteins had not been annotated. 


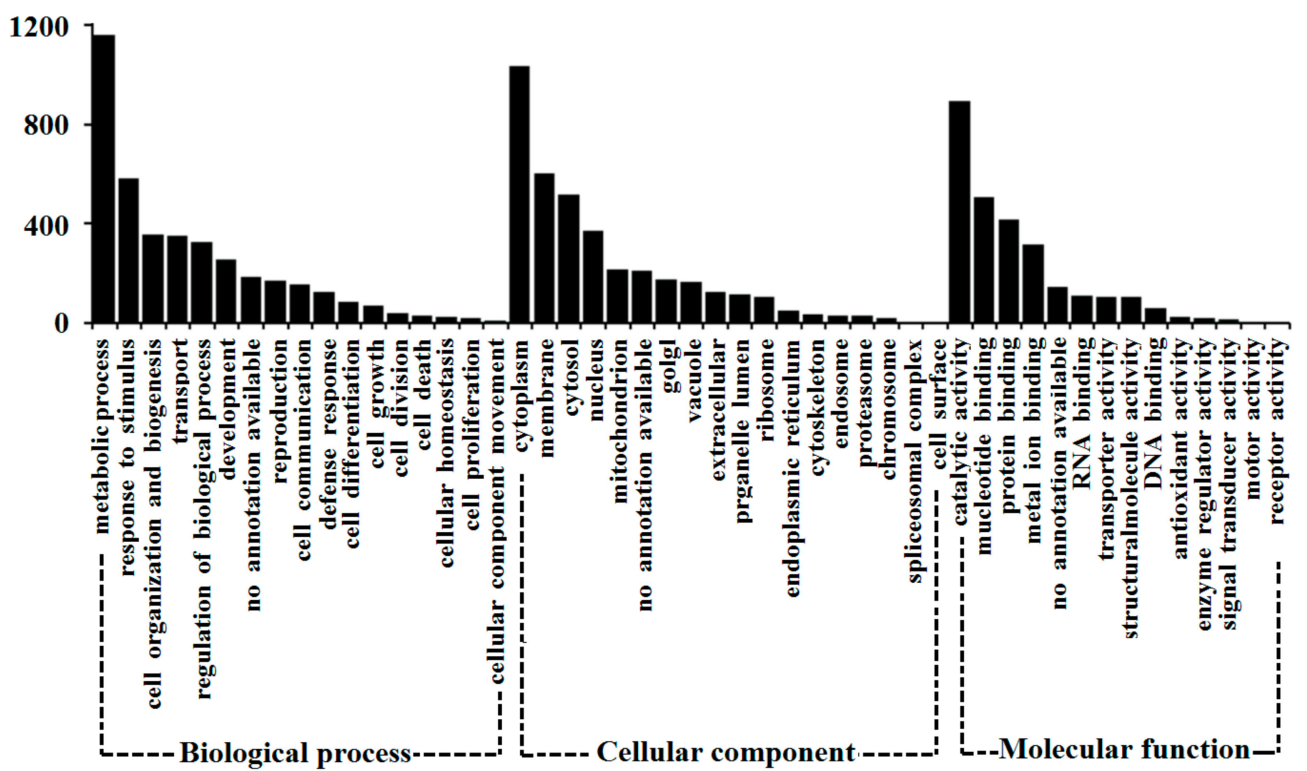

Figure 2. Gene ontology classification of the proteins identified base on Arabidopsis thaliana database.

Among the 1476 proteins, 89 differentially expressed proteins were picked out for quantitative analysis (Figure 3). The classification of 89 different proteins was identified and analyzed in the Arabidopsis thaliana database. In addition, the number of proteins was corresponded to each category, as shown in Figure 4. The 89 proteins corresponded to 39 KEGG pathways, including amino acid metabolism, sugar metabolism, energy metabolism, and secondary metabolites synthesis. The first 10 KEGG pathways were annotated as shown in Table 2 . The 89 different proteins were analyzed by adopting the INTACT and String interaction networks and the results are shown in Figure 5.

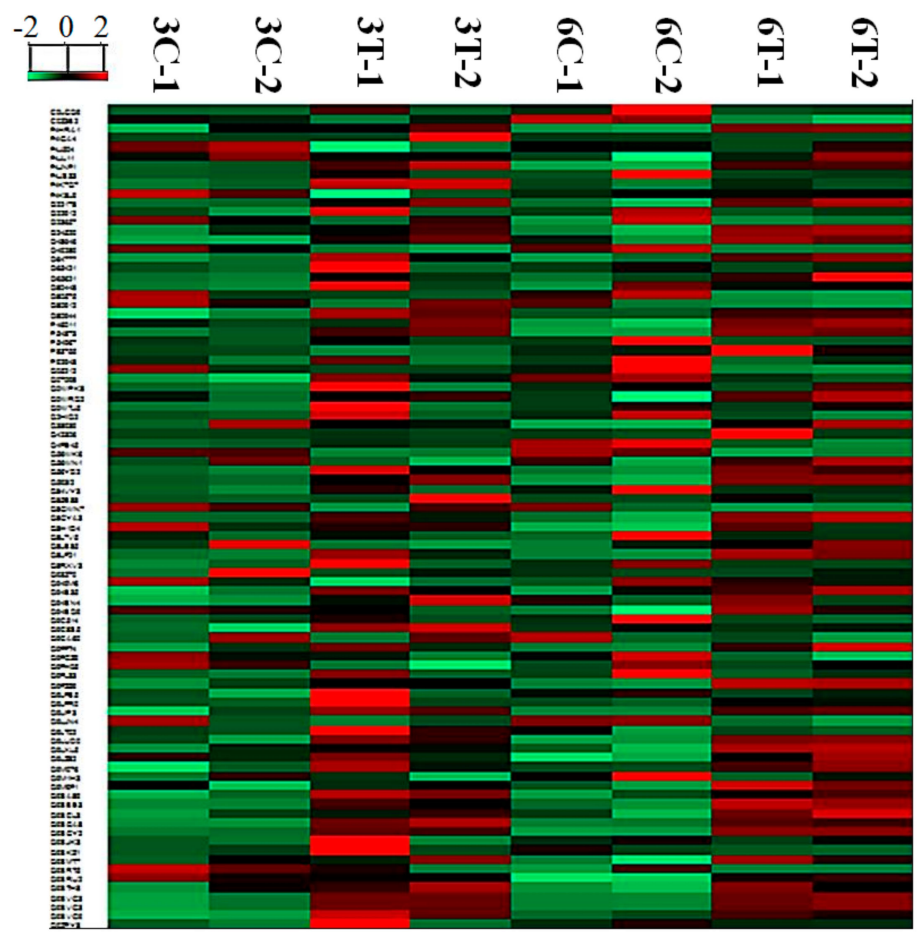

Figure 3. Heatmap of statistically-changed proteins identified based on Arabidopsis thatiana database. High- and low-expression are shown in green and red; $\mathrm{C}$ and $\mathrm{T}$ indicate control and PSF-treated, respectively. 


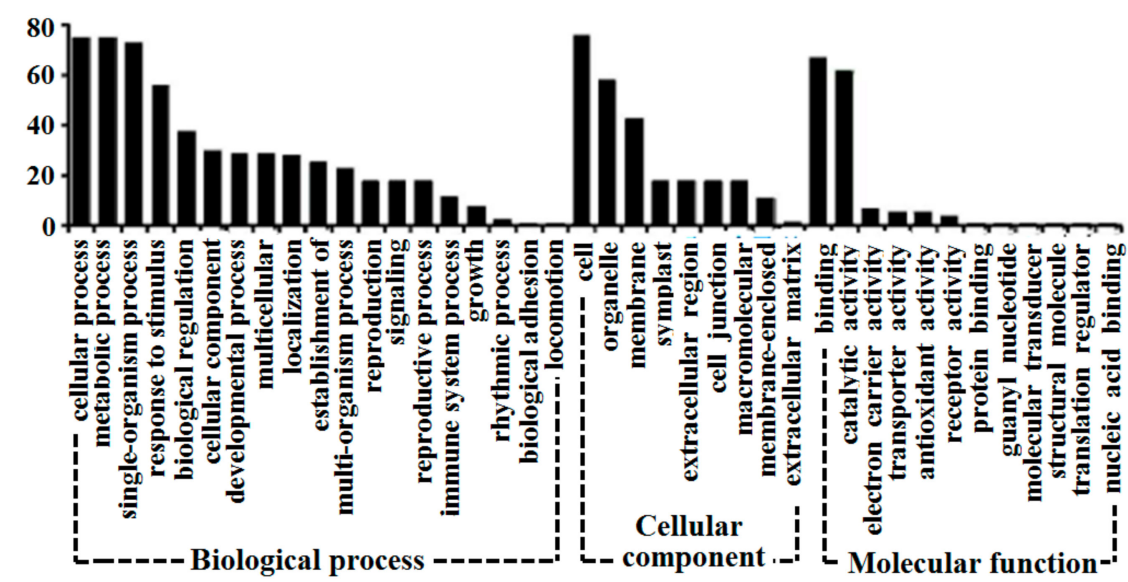

Figure 4. Gene ontology classification of the differential proteins identified based on Arabidopsis thaliana database.

Table 2. The 10 KEGG pathways annotated by major differential proteins.

\begin{tabular}{lcc}
\hline Pathway & Pathway Name & Protein Num. \\
\hline ath00900 & Terpenoid backbone biosynthesis & 5 \\
ath00010 & Glycolysis/gluconeogenesis & 3 \\
ath00460 & Cyanoamino acid metabolism & 3 \\
ath00940 & Phenylpropanoid biosynthesis & 3 \\
ath03040 & Spliceosome & 3 \\
ath00061 & Fatty acid biosynthesis & 2 \\
ath00480 & Glutathione metabolism & 2 \\
ath00590 & Arachidonic acid metabolism & 2 \\
ath00630 & Glyoxylate and dicarboxylate metabolism & 2 \\
ath03013 & RNA transport & 2 \\
\hline
\end{tabular}

KEGG means Kyoto Encyclopedia of Genes and Genomes.

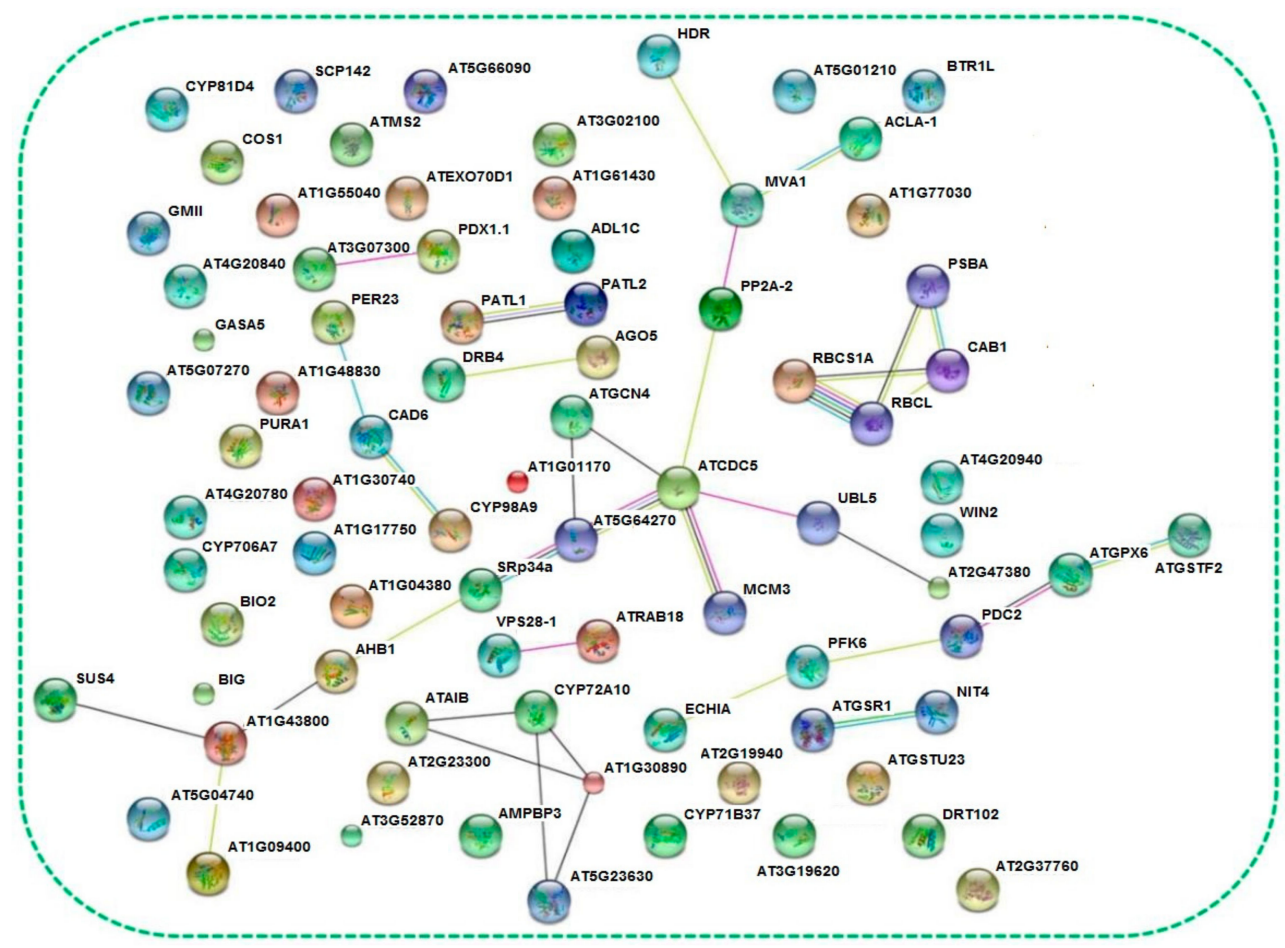

Figure 5. String network of the differential proteins identified based on Arabidopsis thaliana database. 


\subsection{Quantitative Analysis of the 89 Differential Proteins}

For the quantitative analysis, 89 differential proteins were mainly involved in signal transduction, redox, amino acid synthesis and metabolism, protein synthesis and metabolism, the biosynthesis of terpenoids, carbohydrate synthesis, metabolism and transport, and other physiological and biochemical process (Table 3, Figure 6).

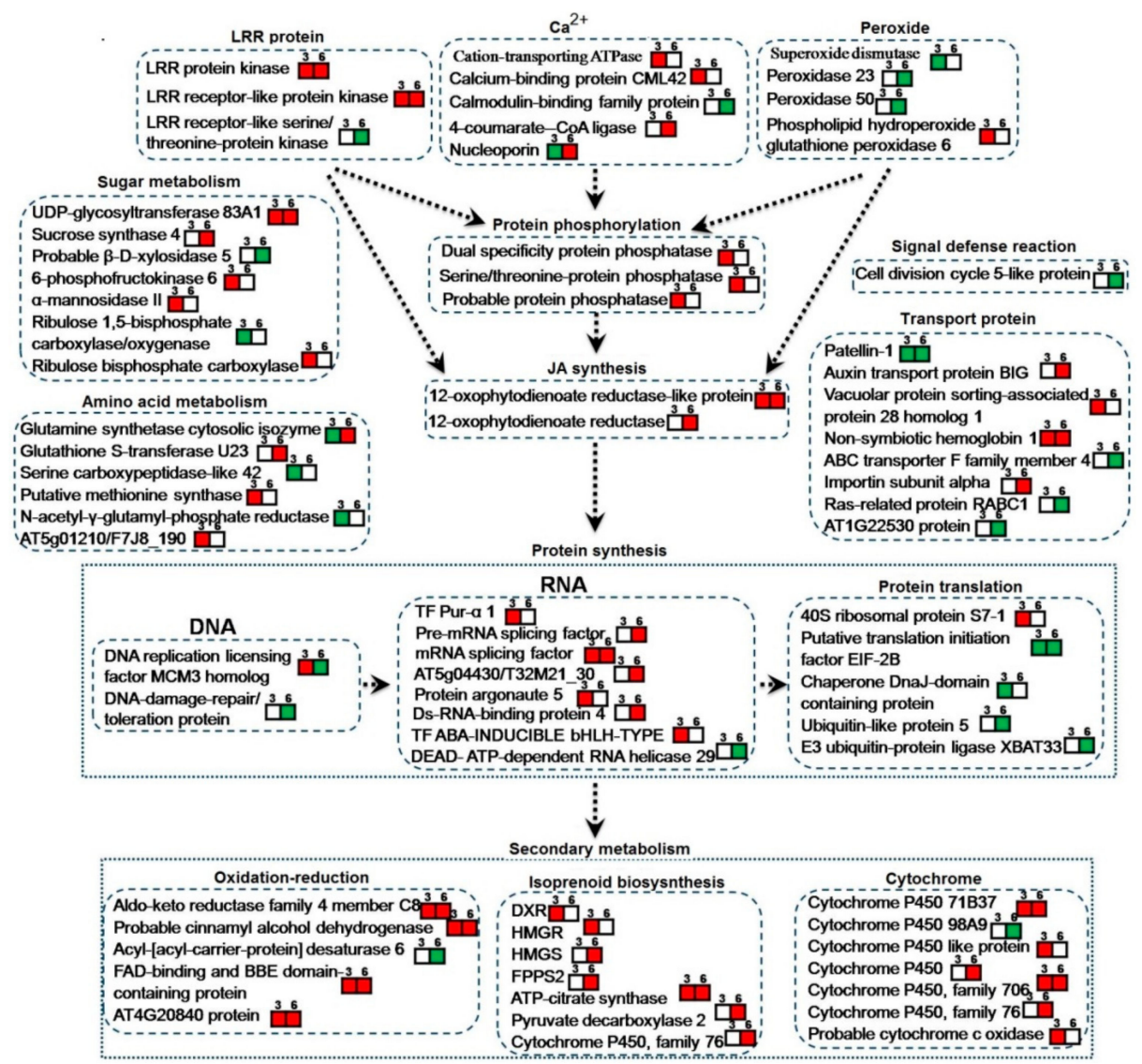

Figure 6. The action network map of 89 differential proteins according to the Arabidopsis thaliana database. The number in the box indicates the number of PSF-treated days, red indicated significant increase and green indicated significant reduction.

The 89 differential proteins in signal transduction involves the leucine-rich repeat (LRR) protein, $\mathrm{Ca}^{2+}$-related protein, peroxidase-related protein, protein phosphorylation protein, and the synthesis of jasmonic acid (JA). We found that two LRR-related proteins significantly increased leucine-rich repeat protein kinase family protein and leucine-rich repeat receptor-like protein kinase PEPR2 under the action of T. atroviride D16PSF on the third day and sixth day in this study, which revealed that the LRR protein plays an important role in promoting S. miltiorrhiza hairy root growth and tanshinone synthesis under the action of T. atroviride D16 PSF. The relative expression of LRR and LRR-PEPR on the fourteenth day of S. miltiorrhiza after culturing in the presence of D16 PSF was also detected. The results revealed that under the sustained action of D16 PSF, a trend showing an increase in LRR and LRR-PEPR is observed (Figure 7). In our study, we also detected that $\mathrm{Ca}^{2+}$-related protein expression changed significantly. The cation-transporting ATPase and calcium-binding protein increased significantly at day three and calmodulin-binding protein (AT3g52870/F8J2_40) decreased significantly on the sixth day and the relative expression of cation-transporting ATPase still increased greatly on the fourteenth day (Figure 7). 4-coumarate-CoA ligase-like 10 increased significantly responding to $\mathrm{Ca}^{2+}$ on the sixth day and nucleoporin related to the level of intracellular $\mathrm{Ca}^{2+}$ decreased on the third day, but increased on the sixth day significantly [18]. These significant changes of $\mathrm{Ca}^{2+}$-related proteins showed 
calcium plays a very important role under the action of T. atroviride D16 PSF in S. miltiorrhiza hairy root. At the same time, we also found superoxide dismutase, peroxidase, and peroxidase 50 associated with peroxide was lowered significantly. 12-oxophytodienoate reductase is a very important key enzyme in the jasmonic acid (JA) biosynthetic pathway, and two proteins, 12-oxophytodienoate reductase-like protein and 12-oxophytodienoate reductase (At1g04380), related with jasmonic acid were found to be significantly higher in this study [19]. Therefore, the effect of T. atroviride D16 PSF on S. miltiorrhiza hairy root may also be related to peroxide, protein phosphorylation, and jasmonic acid.
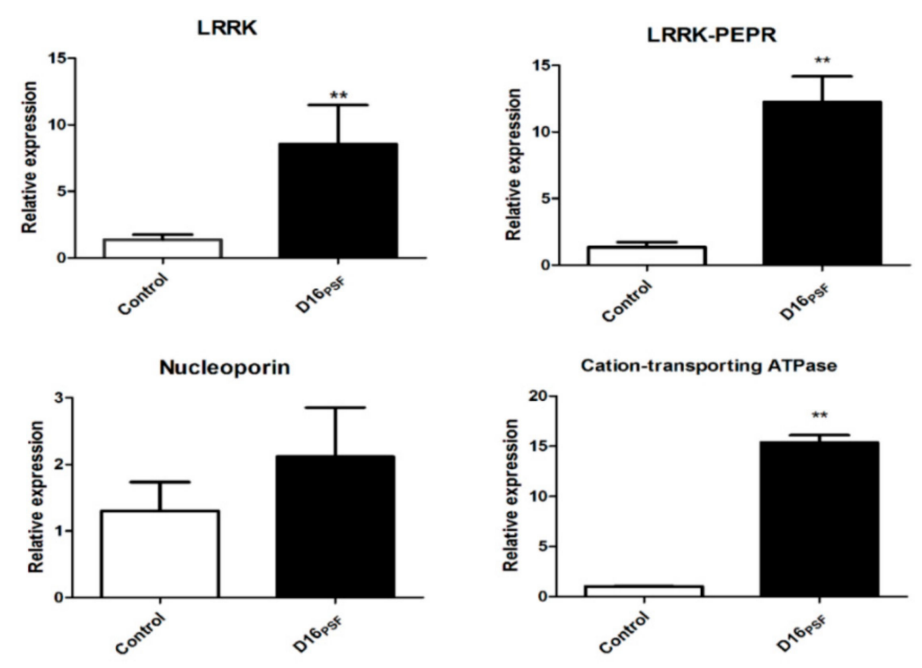

Figure 7. Relative expression of leucine-rich repeat protein kinase (LRRK), leucine-rich repeat protein kinase PEPR (LRR-PEPR), cation-transporting ATPase, and nucleoporin after D16 PSF treatment on the fourteenth day. Values are presented as means $\pm \operatorname{SD}(n=3)$. ${ }^{*} p<0.05 ;{ }^{* *} p<0.01$ versus the control culture.

The 89 differential proteins are mainly involved at the levels of DNA, RNA, and protein translation in protein synthesis. At the level of DNA, the protein-DNA replication licensing factor MCM3 appeared significantly decreased after the first significant rise. DNA and protein damage repair/toleration protein expression was significantly lower on the sixth day. At the level of RNA, transcription factor ABA-inducible bHLH TYPE and transcription factor Pur-alpha 1 was raised significantly on the third day; the pre-mRNA splicing factor SF2-like protein and nuclear protein was also significantly increased. At the level of protein translation, $40 \mathrm{~S}$ ribosomal protein was raised significantly on the third day and the rest of the proteins related to the protein degradation were significantly lower such as chaperone DNAJ domain containing protein, the ubiquitin-like 5 and E3 ubiquitin protein-protein ligase XBAT33. These changes showed T. atroviride D16 PSF played a positive regulatory role in protein synthesis of $S$. miltiorrhiza hairy root at the protein expression level.

In terms of the differential proteins in secondary metabolism, they were mainly involved in the cytochrome P450 enzymes, redox enzyme, and enzymes related to the terpenoid biosynthetic pathway, and most of these proteins increased significantly under the influence of T. atroviride D16 PSF. At the same time, significant changes have taken place in some metabolic activities, like synthesis and metabolism of sugar for providing energy, the amino acid synthesis, and metabolism to provide raw materials for protein synthesis and transporters which have transportation function.

With the deep analysis of these differential expression proteins, it can be presumed that D16 PSF regulates the synthesis and metabolism of saccharides and amino acids, the transcription of genes and the translation of protein through the signal transduction pathways involved in leucine-rich repeat proteins, calcium, peroxides, protein phosphorylation, and jasmonic acid (JA) synthesis. This then results in changes of protein expression involved in secondary metabolism and thus induces metabolic profile changes in S. miltiorrhiza hairy roots. 
Table 3. The differential proteins of S. miltiorrhiza hairy roots after PSF treatment on third day and sixth day.

\begin{tabular}{|c|c|c|c|c|c|c|c|}
\hline Accession & Signal Transduction Description & B/A & $\mathrm{D} / \mathrm{C}$ & Accession & Signal Transduction Description & B/A & $\mathrm{D} / \mathrm{C}$ \\
\hline & Leucine repeated cell proteins and receptors & & & O49289 & Putative DEAD-box ATP-dependent RNA helicase 29 & - & 0.61 \\
\hline $\mathrm{O} 22178$ & Leucine-rich repeat protein kinase family protein & 1.54 & 2.09 & Q9SCL3 & PRE-MRNA SPLICING FACTOR SF2-like protein & - & 1.63 \\
\hline Q9FZ59 & Leucine-rich repeat receptor-like protein kinase PEPR2 & 1.70 & 3.38 & Q56YD2 & Nuclear protein-like & 1.77 & 1.83 \\
\hline \multirow[t]{2}{*}{ C0LGQ9 } & $\begin{array}{c}\text { Probable LRR receptor-like serine/threonine-protein } \\
\text { kinase At4g20940 }\end{array}$ & - & 0.65 & Q9LZ82 & AT5g04430/T32M21_30 & - & 3.06 \\
\hline & Calcium ion and its related proteins & & & Q9SJK3 & Protein argonaute 5 & 1.69 & - \\
\hline Q9SVG9 & Calcium-binding protein CML42 & 1.72 & - & & Protein level & & \\
\hline Q9LT02 & Probable cation-transporting ATPase & 1.53 & - & Q9C514 & $40 \mathrm{~S}$ ribosomal protein $\mathrm{S} 7-1$ & 1.71 & 0.30 \\
\hline Q9SMT7 & 4-coumarate-CoA ligase-like 10 & - & 1.50 & Q9SRT5 & $\begin{array}{l}\text { Putative translation initiation factor EIF-2B beta subunit, } \\
3^{\prime} \text { partial (Fragment) }\end{array}$ & 0.57 & 0.64 \\
\hline Q8L7V5 & AT3g52870/F8J2_40 & - & 0.51 & F4K8L9 & Chaperone DnaJ-domain containing protein & 0.51 & - \\
\hline \multirow[t]{2}{*}{ F4IGA4 } & Nucleoporin, Nup133/Nup155-like protein & 0.41 & 12.75 & Q9FGZ9 & Ubiquitin-like protein 5 & - & 0.64 \\
\hline & Protein phosphorylase & & & Q4FE45 & E3 ubiquitin-protein ligase XBAT33 & - & 0.49 \\
\hline F4K7Q7 & Dual specificity protein phosphatase family protein & 2.04 & - & & Terpene biosynthesis & & \\
\hline Q07098 & $\begin{array}{l}\text { Serine/threonine-protein phosphatase PP2A-2 catalytic } \\
\text { subunit }\end{array}$ & 1.50 & - & Q9SGY2 & ATP-citrate synthase alpha chain protein 1 & 1.65 & 2.07 \\
\hline \multirow[t]{2}{*}{ Q8RXV3 } & Probable protein phosphatase $2 C 59$ & 1.75 & - & Q9FFT4 & Pyruvate decarboxylase 2 & - & 1.72 \\
\hline & Jasmonic acid synthesis & & & Q9XFS9 & $\begin{array}{l}\text { 1-deoxy-D-xylulose 5-phosphate reductoisomerase, } \\
\text { chloroplastic }\end{array}$ & 1.54 & - \\
\hline Q8GYA3 & Putative 12-oxophytodienoate reductase-like protein 1 & 1.64 & 2.96 & Q94B35 & $\begin{array}{l}\text { 4-hydroxy-3-methylbut-2-enyl diphosphate reductase, } \\
\text { chloroplastic }\end{array}$ & 1.54 & - \\
\hline \multirow[t]{2}{*}{ Q593I2 } & At1g04380 (Fragment) & - & 2.08 & P54873 & Hydroxymethylglutaryl-CoA synthase & - & 1.60 \\
\hline & Peroxidase & & & F4JNF1 & Farnesyl diphosphate synthase 2 & - & 1.50 \\
\hline F4J504 & Superoxide dismutase & 0.64 & - & F4HRA1 & Cytochrome P450, family 76, subfamily C, polypeptide 5 & - & 2.24 \\
\hline O80912 & Peroxidase 23 & - & 0.35 & & Carbohydrate synthesis and metabolism & & \\
\hline F4JS33 & Peroxidase 50 & - & 0.49 & Q9SGA8 & UDP-glycosyltransferase 83A1 & 3.47 & 2.41 \\
\hline \multirow[t]{2}{*}{ O48646 } & $\begin{array}{l}\text { Probable phospholipid hydroperoxide glutathione } \\
\text { peroxidase } 6\end{array}$ & 1.52 & - & Q9LXL5 & Sucrose synthase 4 & - & 1.59 \\
\hline & Signal transduction defense & & & Q9LJN4 & Probable beta-D-xylosidase 5 & - & 0.56 \\
\hline \multirow[t]{3}{*}{ P92948 } & Cell division cycle 5-like protein & - & 0.60 & Q9M076 & 6-phosphofructokinase 6 & 1.85 & - \\
\hline & Oxidation and reduction & & & Q9LFR0 & Alpha-mannosidase II & 1.71 & - \\
\hline & Oxidoreductase & & & Q85B88 & $\begin{array}{c}\text { Ribulose 1,5-bisphosphate carboxylase/oxygenase large } \\
\text { chain (Fragment) }\end{array}$ & 2.71 & - \\
\hline
\end{tabular}


Table 3. Cont.

\begin{tabular}{|c|c|c|c|c|c|c|c|}
\hline Accession & Signal Transduction Description & $\mathbf{B} / \mathbf{A}$ & $\mathrm{D} / \mathrm{C}$ & Accession & Signal Transduction Description & $\mathbf{B} / \mathbf{A}$ & $\mathrm{D} / \mathrm{C}$ \\
\hline O80944 & Aldo-keto reductase family 4 member C8 & 2.65 & 1.56 & Q42306 & $\begin{array}{l}\text { Ribulose bisphosphate carboxylase small chain } \\
\text { (Fragment) }\end{array}$ & - & 12.36 \\
\hline O65621 & Probable cinnamyl alcohol dehydrogenase 6 & 1.85 & 2.69 & & Transport protein & & \\
\hline Q84VY3 & Acyl-[acyl-carrier-protein] desaturase 6, chloroplastic & - & 0.66 & Q56WK6 & Patellin-1 & 0.65 & 0.57 \\
\hline Q9SA89 & FAD-binding and BBE domain-containing protein & 2.25 & 1.67 & Q9SRU2 & Auxin transport protein BIG & - & 1.71 \\
\hline \multirow[t]{2}{*}{ Q9SVG3 } & AT4G20840 protein & 2.68 & 2.61 & O65421 & $\begin{array}{c}\text { Vacuolar protein sorting-associated protein } 28 \text { homolog } \\
1\end{array}$ & 2.40 & - \\
\hline & Cytochrome & & & $\mathrm{O} 24520$ & Non-symbiotic hemoglobin 1 & 1.92 & 5.16 \\
\hline Q9LIP3 & Cytochrome P450 71B37 & 1.73 & 1.65 & Q9M1H3 & $\mathrm{ABC}$ transporter $\mathrm{F}$ family member 4 & - & 0.62 \\
\hline Q9CA60 & Cytochrome P450 98A9 & - & 0.58 & F4JL11 & Importin subunit alpha & - & 1.87 \\
\hline Q0WTJ5 & Cytochrome P450 like protein (Fragment) & 1.81 & - & $\mathrm{O} 23657$ & Ras-related protein RABC1 & - & 0.59 \\
\hline Q9LUD0 & Cytochrome P450 & - & 1.51 & C0Z3B2 & AT1G22530 protein & - & 0.60 \\
\hline Q9STH8 & $\begin{array}{l}\text { Cytochrome P450, family } 706 \text {, subfamily A, polypeptide } \\
7\end{array}$ & 1.52 & 2.09 & & Other functional protein & & \\
\hline F4HRA1 & Cytochrome P450, family 76, subfamily C, polypeptide 5 & - & 2.24 & P54967 & Biotin synthase & - & 0.38 \\
\hline \multirow[t]{2}{*}{$\mathrm{O} 22912$} & Probable cytochrome coxidase subunit $5 \mathrm{C}-1$ & 1.72 & - & O80575 & 6,7-dimethyl-8-ribityllumazine synthase, chloroplastic & - & 0.64 \\
\hline & Synthesis and metabolism of amino acids & & & P46011 & Bifunctional nitrilase/nitrile hydratase NIT4 & - & 1.57 \\
\hline Q56WN1 & Glutamine synthetase cytosolic isozyme 1-1 & 0.52 & 1.67 & Q9C8S5 & $\begin{array}{c}\text { Chlorophyll A-B-binding protein 2, 5' partial; 1-750 } \\
\text { (Fragment) }\end{array}$ & 1.64 & - \\
\hline Q9M9F1 & Glutathione S-transferase U23 & - & 1.63 & Q8LF21 & Dynamin-related protein $1 \mathrm{C}$ & _- & 1.5 \\
\hline Q9FH05 & Serine carboxypeptidase-like 42 & 0.66 & - & QOWRQ2 & Enoyl-CoA hydratase like protein & - & 1.52 \\
\hline Q94BN4 & Putative methionine synthase & 1.63 & - & Q38939 & GASA5 & - & 1.78 \\
\hline Q93Z70 & $\begin{array}{l}\text { Probable N-acetyl-gamma-glutamyl-phosphate } \\
\text { reductase, chloroplastic }\end{array}$ & 0.6 & - & Q949M6 & Putative uncharacterized protein At1g55040 & 0.48 & - \\
\hline \multirow[t]{3}{*}{ Q9LFB5 } & AT5g01210/F7J8_190 & 1.73 & - & Q0WPK8 & Putative uncharacterized protein At1g72470 & 1.77 & - \\
\hline & Protein synthesis and degradation & & & & Unknown protein & & \\
\hline & DNA level & & & Q94BQ9 & Integral membrane HRF1-like protein & - & 1.64 \\
\hline Q9FL33 & DNA replication licensing factor MCM3 homolog & 1.90 & 0.53 & P83755 & Photosystem $\mathrm{Q}(\mathrm{B})$ protein & - & 1.97 \\
\hline \multirow[t]{2}{*}{ Q05212 } & DNA-damage-repair/toleration protein DRT102 & - & 0.64 & Q8GWN7 & Putative uncharacterized protein At5g66090/K2A18_17 & 0.66 & 0.53 \\
\hline & RNAlevel & & & Q8LB85 & Putative uncharacterized protein & 0.58 & - \\
\hline Q8H1D4 & Double-stranded RNA-binding protein 4 & - & 2.28 & Q9SBE3 & T14P8.11 (Fragment) & 3.91 & 5.23 \\
\hline Q9ZPY8 & Transcription factor ABA-INDUCIBLE bHLH-TYPE & 1.75 & - & Q2HIQ2 & At1g01170 & - & 0.65 \\
\hline Q9SKZ1 & Transcription factor Pur-alpha 1 & 1.91 & - & & & & \\
\hline
\end{tabular}

Note: B/A and D/C are 3 and 6 days, respectively, dealing with the ratio of the amount of protein group and the blank group, 1.5 or higher to increase protein, 0.66 or less for cut protein, "-" indicates no difference. GASA5, GA-Stimulated in Arabidopsis; LRR, Leucine-rich repeat. 


\section{Discussion}

It is known that protein is the carrier of gene function and the executor of the life activities. The high-throughput and large-scale proteomics to study time changes of the expression of all the proteins in the cell or tissue can reveal the physiological and biochemical processes in detail $[20,21]$. At present, proteomics research mainly is based on the separation of the gel and the liquid phase. The methods based on gel separation include two-dimensional electrophoresis proteomics research and fluorescent difference gel electrophoresis (DIGE) proteomics research, mainly through the gel electrophoresis separation of mixed protein samples. After getting various single protein points, we can screen differential proteins according to the dyed color and identify proteins through the MALDI-MS finally. Methods based on the liquid phase include label-free proteomics research, marked iTRAQ/SILAC proteomics research, and SRM/MRM proteomics research, mainly by means of liquid phase to separate mixed protein samples and through the mass spectrometer connected directly with liquid phase for qualitative and quantitative analysis [22]. Proteomics technology has been widely used in plant growth and development, plant adaptation mechanism to biological and abiotic stress, and the interaction mechanism of microbes [23,24]. iTRAQ (isobaric tags for relative and absolute quantitation) technology is a kind of proteomics technology through four or eight kinds of isotope labels specifically to mark amino groups of polypeptides, and then to identify and separate proteins by LC-MS and analyze relative and absolute content of different protein samples according to the isotope intensity $[25,26]$. This experiment adopted the iTRAQ technology to tag eight $S$. miltiorrhiza hairy root samples of control group and T. atroviride D16 PSF on the third and sixth day.

Leucine-rich repeat (LRR) protein kinase family proteins are the largest known type of transmembrane receptor protein kinases in plants, which have the function of regulation in plant growth and development, hormone signal transduction, and biological and non-biological stress response [27,28]. LRR proteins play a critical role in the process of Piriformospora indica promoting growth of Arabidopsis thaliana [29,30]. As studied, Pep1 is a 23-amino acid peptide that enhances resistance to a root pathogen, Pythium irregulare. Pep1 and its homologs (Pep2 to Pep7) are endogenous amplifiers of innate immunity of Arabidopsis thaliana that induce the transcription of defense-related genes and bind to PEPR1, a plasma membrane leucine-rich repeat (LRR) receptor kinase [31]. Our present results revealed that $T$. atroviride D16 PSF could gradually enhance the LRR protein kinase family protein and LRR receptor-like protein kinase PEPR2 in hairy roots of S. miltiorrhiza. The LRR receptor-like protein kinase PEPR2 might strengthen the ability of resisting T. atroviride D16 PSF, whereas the expression of probable LRR receptor-like serine/threonine-protein kinase At4g20940 decreased. CML42 are calcium-binding proteins that are thought to function as plant signal transduction elements, and were up-regulated and induced by Spodoptera littoralis in Arabidopsis thaliana followed by $\mathrm{Ca}^{2+}$ and phytohormone elevation [32,33]. In addition, CML42 enhanced the content of aliphatic glucosinolate and hyperactivated transcript accumulation of the jasmonic acid (JA)-responsive genes through the negative regulation of the jasmonate receptor Coronatine Insensitive1 (COI 1). As proteomics analysis revealed, this was expressed 1.7-fold higher in S. miltiorrhiza hairy root on the third day, which indicated T. atroviride D16 PSF may regulate $\mathrm{Ca}^{2+}$ and JA elevation. It has been reported that CML42 was not only involved in abiotic stress responses and insect herbivory defense, but also related to trichomes branching and endophytic fungi stimulation as a $\mathrm{Ca}^{2+}$ sensor, indicating CML42 is an important calcium-binding protein in plant growth and defense processes. Nucleoporin is a component of the nuclear pore complex, which has strongly attracted the attention of its involvement in hormonal and pathogen/symbiotic signaling [34,35]. $\mathrm{Ca}^{2+}$ signal transduction is important in the interaction between microorganisms and plants [36,37]. In the present study, as a key nucleoprotein, the Nup133/Nup155-like protein had a sharp rise on the third day as well as a substantial decrease in S. miltiorrhiza hairy root under the treatment of T. atroviride D16 PSF. The present results revealed that Nup133 are essential for mRNA export, and the Nup133/Nup155-like protein may regulate the symbiotic signaling transduction and S. miltiorrhiza response via mRNA export. 
Cation-transporting ATPase is an enzyme protein widely found in biological membranes. Its structure and function is complex and plays an important regulatory role in the biological activities of cells [38]. PDE1 is an encoded P-type ATPase, which is required for the maintenance of phospholipid asymmetry in biological membranes, as membrane asymmetry may play a critical role in the development of infection hyphae by phytopathogenic fungi. The cation-transporting ATPase was up-regulated and induced by T. atroviride D16 PSF on the third day, and may provide a chance for interacting with S. miltiorrhiza hairy root. The 4-coumarate-Co-A ligase (4CL)-like proteins belong to the adenosine monophosphate (AMP)-binding domain-containing proteins family and widely exist in various plant species [39]. AMP-binding domain-containing 4CLs are critical enzymes in the phenylpropanoid metabolism pathway and drive the carbon flow from primary metabolism to different branches of secondary metabolism in plants [40]. Along with the tanshinones accumulation, the 4-coumarate-Co-A ligase (4CL)-like 10 protein were raised on the sixth day. In support, the 4-coumarate-Co-A ligase (4CL) like protein was up-regulated by Magnaporthe oryzae infection, which may be a defense-related AMP-binding protein (AMPBP) that is involved in the regulation of the defense response through salicylic acid (SA) and/or jasmonic acid (JA)/ ethylene (ET) signaling pathways. Phosphoprotein phosphatases (PPP) are present in all eukaryotic organisms, which is an ancient and important regulatory enzyme. The protein phosphatase 2Cs (PP2Cs) from various organisms have been implicated to act as negative modulators of protein kinase pathways involved in diverse environmental stress responses and developmental processes [41]. The Ser/Thr-specific phosphatases are metal-dependent enzymes divided into two major families: The PPP family, which includes protein phosphatases 1, 2A, and 2B (PP1, PP2A, PP2B/calcineurin); and the PPM family, which includes PP2C, which is a highly ABA-induced protein in guard cells once found in Arabidopsis and induced by endophyte fungi T. atroviride D16 PSF as well in this study. In addition, dual specificity protein phosphatases were significantly higher on the third day, referring to serine/threonine protein phosphatase and probable protein phosphatase related to protein phosphorylation [42]. T. atroviride D16 PSF induced high expression of protein phosphatase 2C and serine/threonine-protein phosphatase PP2A-2 through ABA signaling in S. miltiorrhiza hairy root. 12-oxophytodienoate reductase-like protein 1 is an enzyme in the jasmonic acid (JA) biosynthesis pathway [43], and the expression of 12-oxophytodienoate reductase-like protein 1 was gradually enhanced under the treatment of T. atroviride D16 PSF involved in the JA biosynthetic pathway. Superoxide dismutases (SODs) are involved in plant adaptive responses to biotic and abiotic stresses although the upstream signaling process which modulates their expression is not clearly understood [44]. Surprisingly, the level of SOD and peroxides were decreased at the treatment of T. atroviride D16 PSF, while plant overexpressing antioxidant enzymes had higher tolerance to external stress [45]. Phospholipid hydroperoxide glutathione peroxidase (PHGPX) is the principal enzymatic defense against oxidative destruction of biomembranes [46], and its major function appears to be the scavenging of phospholipid hydroperoxides, thereby protecting cell membranes from peroxidative damage. Gene expression analysis has shown an increase in the levels of PHGPX mRNA in several plant species undergoing different biotic and abiotic stresses, such as pathogen infections, high salt concentrations, exposure to heavy metals, mechanical stimulation, aluminum toxicity, seed germination, salt and osmotic stress, oxidative stress, and chilling stress [47]. PHGPXs may play dual roles as a redox transducer in addition to acting as a $\mathrm{H}_{2} \mathrm{O}_{2}$ scavenger under stress, thus PHGPX proteins may have different functions in plant cells, with some isoforms functioning in the signal transduction pathway, while others are involved in catalyzing the reduction of harmful products formed by ROS. The effect of various signaling molecules (salicylic acid, JA, ABA, ethylene) and certain protein phosphatase inhibitors (cantharidin and endothall) on the expression of the PHGPX gene in rice seedling leaves has demonstrated an up-regulation of the mRNA levels. These data suggest the role of this enzyme in the induction of defense mechanisms in plant cells subjected to oxidative damage, as a result of exposure to various environmental stresses, is by reducing the phospholipid hydroperoxides formed in the biomembranes. 


\section{Conclusions}

Collectively, the analysis indicated that 89 differentially abundant proteins were involved mainly in protein synthesis, protein folding and degradation, biotic stress defense, photosynthesis, RNA process, signal transduction, and other functions. When induced by T. atroviride D16 PSF, S. miltiorrhiza hairy roots generally respond through elucidating the synthesis of tanshinones. These results provided valuable information for T. atroviride D16 PSF inducing tanshinones accumulation of S. miltiorrhiza. Characterization of PSF and proteomics provided an important bioinformatic resource for investigating mechanisms in inducing tanshinones accumulation.

Author Contributions: Conceptualization, L.-p.Q. and T.H.; methodology, W.P., Q.-1.M. and X.Z.; software, X.Z. and Q.Z.; validation, L.-p.Q. and T.H.; formal analysis, Q.-1.M., X.Z. and Q.Z.; investigation, W.P., Q.-1.M., X.Z. and S.-J.W.; resources, T.H.; data curation, Q.-1.M. and X.Z.; writing-original draft preparation, W.P., X.Z. and Q.Z.; writing-review and editing, K.R., T.H. and L.-p.Q.; visualization, Q.-1.M. and X.Z.; supervision, T.H. and L.-p.Q.; project administration, T.H.; funding acquisition, T.H. and L.-p.Q.

Funding: This research was funded by the National Natural Science Foundation of China, grant number 81872953 and the Shanghai Pujiang Program, grant number 18PJD061.

Conflicts of Interest: The authors declare no conflicts of interest.

\section{References}

1. Wang, L.; Ma, R.; Liu, C.; Liu, H.; Zhu, R.; Guo, S.; Tang, M.; Li, Y.; Niu, J.; Fu, M.; et al. Salvia miltiorrhiza: A potential red light to the development of cardiovascular diseases. Curr. Pharm. Des. 2017, 23, 1077-1097. [CrossRef] [PubMed]

2. Ren, J.; Fu, L.; Nile, S.H.; Zhang, J.; Kai, G. Salvia miltiorrhiza in treating cardiovascular diseases: A review on its pharmacological and clinical applications. Front. Pharmacol. 2019, 10, 753. [CrossRef] [PubMed]

3. Jiang, Z.; Gao, W.; Huang, L. Tanshinones, critical pharmacological components in Salvia miltiorrhiza. Front. Pharmacol. 2019, 10, 202. [CrossRef] [PubMed]

4. Zhang, B.; Zheng, L.P.; Wang, J.W. Nitric oxide elicitation for secondary metabolite production in cultured plant cells. Appl. Microbiol. Biotechnol. 2012, 93, 455-466. [CrossRef] [PubMed]

5. Wang, H.; Yang, X.; Guo, L.; Zeng, H.; Qiu, D. PeBL1, a novel protein elicitor from Brevibacillus laterosporus strain A60, activates defense responses and systemic resistance in Nicotiana benthamiana. Appl. Environ. Microbiol. 2015, 81, 2706-2716. [CrossRef] [PubMed]

6. $\quad$ Ming, Q.; Su, C.; Zheng, C.; Jia, M.; Zhang, Q.; Zhang, H.; Rahman, K.; Han, T.; Qin, L. Elicitors from the endophytic fungus Trichoderma atroviride promote Salvia miltiorrhiza hairy root growth and tanshinone biosynthesis. J. Exp. Bot. 2013, 64, 5687-5694. [CrossRef] [PubMed]

7. Bohlmann, H.; Vignutelli, A.; Hilpert, B.; Miersch, O.; Wasternack, C.; Apel, K. Wounding and chemicals induce expression of the Arabidopsis thaliana gene Thi2.1, encoding a fungal defense thionin, via the octadecanoid pathway. FEBS Lett. 1998, 437, 281. [CrossRef]

8. Smeekens, S. Sugar- induced signal transduction in plants. Ann. Rev. Plant Physiol. Plant Mol. Biol. 2000, 51, 49-81. [CrossRef]

9. Wang, H.; Zhang, X.; Dong, P.; Luo, Y.; Cheng, F. Extraction of polysaccharides from Saccharomyces cerevisiae and its immune enhancement activity. Int. J. Pharmacol. 2013, 9, 288-296.

10. Chen, F.; Ren, C.G.; Zhou, T.; Wei, Y.J.; Dai, C.C. A novel exopolysaccharide elicitor from endophytic fungus Gilmaniella sp. AL12 on volatile oils accumulation in Atractylodes lancea. Sci. Rep. 2016, 6, 120-125. [CrossRef]

11. Escribano, J.; Rubio, A.; Alvarez-Ortí, M.; Molina, A.; Fernández, J.A. Purification and characterization of a mannan-binding lectin specifically expressed in corms of saffron plant (Crocus sativus L.). J. Agric. Food Chem. 2000, 48, 451-457. [CrossRef] [PubMed]

12. Schulz, B.; Rommert, A.K.; Dammann, U.; Aust, H.J.; Strack, D. The endophyte-host interaction: A balanced antagonism? Mycol. Res. 1999, 103, 1275-1283. [CrossRef]

13. Zhang, H.Y.; Lei, G.; Zhou, H.W.; He, C.; Liao, J.L.; Huang, Y.J. Quantitative iTRAQ-based proteomic analysis of rice grains to assess high night temperature stress. Proteomics 2017, 2, 160-165. [CrossRef] [PubMed] 
14. Zhang, Z.; Zhou, H.; Yu, Q.; Li, Y.; Mendoza-Cózatl, D.G.; Qiu, B.; Liu, P.; Chen, Q. Quantitative proteomics investigation of leaves from two Sedum alfredii (Crassulaceae) populations that differ in cadmium accumulation. Proteomics 2017, 17, 210-216.

15. Kaul, S.; Sharma, T.; Dhar, M.K. “Omics” tools for better understanding the plant endophyte interactions. Front. Plant Sci. 2016, 7, 955. [CrossRef] [PubMed]

16. Alidrus, A.; Carpentier, S.C.; Ahmad, M.T.; Panis, B.; Mohamed, Z. Elucidation of the compatible interaction between banana and Meloidogyne incognitavia high-throughput proteome profiling. PLoS ONE 2017, 12, e0178438.

17. Gadjeva, M.; Thiel, S.; Jensenius, J.C. The mannan-binding-lectin pathway of the innate immune response. Curr. Opin. Immunol. 2001, 13, 74-78. [CrossRef]

18. Liu, H.; Guo, Z.; Gu, F.; Ke, S.; Sun, D.; Dong, S.; Liu, W.; Huang, M.; Xiao, W.; Yang, G. 4-Coumarate-CoA ligase-Like gene OsAAE3 negatively mediates the rice blast resistance, floret development and lignin biosynthesis. Front. Plant Sci. 2016, 7, 13-21. [CrossRef]

19. Wasternack, C. Jasmonates: An update on biosynthesis, signal transduction and action in plant stress response, growth and development. Ann. Bot. 2007, 100, 681-697. [CrossRef]

20. Song, C.; Zeng, F.; Wu, F.; Ma, W.; Zhang, G. Proteomic analysis of nitrogen stress-responsive proteins in two rice cultivars differing in $\mathrm{N}$ utilization efficiency. J. Integr. Omics 2011, 1, 12-19.

21. He, C.Y.; Zhang, G.Y.; Zhang, J.G.; Duan, A.G.; Luo, H.M. Physiological, biochemical, and proteome profiling reveals key pathways underlying the drought stress responses of Hippophae rhamnoides. Proteomics 2016, 16, 2688-2697. [CrossRef] [PubMed]

22. Ruan, S.L.; Ma, H.S.; Wan, S.H.; Xin, Y.; Qian, L.H.; Tong, J.X.; Wang, J. Advances in plant proteomics-I. Key techniques of proteome. Yi Chuan 2006, 28, 1472-1486. [CrossRef] [PubMed]

23. Jiang, Q.; Li, X.; Niu, F.; Sun, X.; Hu, Z.; Zhang, H. iTRAQ-based quantitative proteomic analysis of wheat roots in response to salt stress. Proteomics 2017, 17, 160-165. [CrossRef] [PubMed]

24. Yang, C.; Xu, L.; Zhang, N.; Islam, F.; Song, W.; Hu, L.; Liu, D.; Xie, X.; Zhou, W. iTRAQ-based proteomics of sunflower cultivars differing in resistance to parasitic weed Orobanche cumana. Proteomics 2017, 1, 120-127. [CrossRef] [PubMed]

25. Kambiranda, D.; Katam, R.; Basha, S.M.; Siebert, S. iTRAQ-based quantitative proteomics of developing and ripening muscadine grape berry. J. Proteome Res. 2014, 13, 555-569. [CrossRef] [PubMed]

26. Zheng, B.B.; Fang, Y.N.; Pan, Z.Y.; Sun, L.; Deng, X.X.; Grosser, J.W.; Guo, W.W. iTRAQ-based quantitative proteomics analysis revealed alterations of carbohydrate metabolism pathways and mitochondrial proteins in a male sterile cybrid pummelo. J. Proteome Res. 2014, 13, 299-318. [CrossRef]

27. Keerthisinghe, S.; Nadeau, J.A.; Lucas, J.R.; Nakagawa, T.; Sack, F.D. The Arabidopsis leucine-rich repeat receptor-like kinase MUSTACHES enforces stomatal bilateral symmetry in Arabidopsis. Plant J. Cell Mol. Biol. 2015, 81, 684-694. [CrossRef]

28. Zhou, F.; Yong, G.; Qiu, L.J. Genome-wide identification and evolutionary analysis of leucine-rich repeat receptor-like protein kinase genes in soybean. BMC Plant Biol. 2016, 16, 58-64. [CrossRef]

29. Shahollari, B.; Vadassery, J.; Varma, A.; Oelmüller, R. A leucine-rich repeat protein is required for growth promotion and enhanced seed production mediated by the endophytic fungus Piriformospora indica in Arabidopsis thaliana. Plant J. 2007, 50, 1-13. [CrossRef]

30. Park, S.J.; Moon, J.C.; Yong, C.P.; Kim, J.H.; Dong, S.K.; Jang, C.S. Molecular dissection of the response of a rice leucine-rich repeat receptor-like kinase (LRR-RLK) gene to abiotic stresses. J. Plant Physiol. 2014, 171, 1645-1649. [CrossRef]

31. Yamaguchi, Y.; Huffaker, A.; Bryan, A.C.; Tax, F.E.; Ryan, C.A. PEPR2 is a second receptor for the Pep1 and Pep2 peptides and contributes to defense responses in Arabidopsis. Plant Cell 2010, 22, 508-522. [CrossRef] [PubMed]

32. Stephanie, D.; David, C.; Polly, L.; Steven, P.S.; Snedden, W.A. The calmodulin-related calcium sensor CML42 plays a role in trichome branching. J. Biol. Chem. 2009, 284, 31647-31657.

33. Vadassery, J.; Reichelt, M.; Hause, B.; Gershenzon, J.; Boland, W.; Mithöfer, A. CML42-mediated calcium signaling coordinates responses to spodoptera herbivory and abiotic stresses in Arabidopsis. Plant physiol. 2012, 159, 1159-1175. [CrossRef] [PubMed]

34. Vasu, S.; Shah, S.; Orjalo, A.; Park, M.; Fischer, W.; Forbes, D. Novel vertebrate nucleoporins Nup133 and Nup160 play a role in mRNA export. J. Cell Biol. 2001, 155, 339-341. [CrossRef] [PubMed] 
35. Martin, B.; Thoe, F.A.; Doan-Trung, L.; Hervé, S.; Isabelle, G.; Isabelle, C. Reduced expression of AtNUP62 nucleoporin gene affects auxin response inArabidopsis. BMC Plant Biol. 2016, 16, 2-10.

36. Wenping, H.; Yuan, Z.; Jie, S.; Lijun, Z.; Zhezhi, W. De novo transcriptome sequencing in Salvia miltiorrhiza to identify genes involved in the biosynthesis of active ingredients. Genomics 2011, 98, 272-279. [CrossRef]

37. Snedden, W.A.; Fromm, H. Calmodulin as a versatile calcium signal transducer in plants. New Phytol. 2001, 151, 35-66. [CrossRef]

38. Balhadère, P.V.; Talbot, N.J. PDE1 encodes a P-type ATPase involved in appressorium-mediated plant infection by the rice blast fungus Magnaporthe grisea. Plant Cell 2001, 13, 1987-1991. [CrossRef]

39. Zhang, X.C.; Yu, X.; Zhang, H.J.; Song, F.M. Molecular characterization of a defense-related AMP-binding protein gene, OsBIABP1, from rice. Biomed Biotechnol. 2009, 10, 731-739. [CrossRef]

40. Soltani, B.M.; Ehlting, J.; Douglas, C.J. Genetic analysis and epigenetic silencing of At4CL1 and At4CL2 expression in transgenic Arabidopsis. Biotechnol. J. 2006, 1, 1124-1136. [CrossRef]

41. Xue, T.; Wang, D.; Zhang, S.; Ehlting, J.; Ni, F.; Jakab, S.; Zheng, C.; Zhong, Y. Genome-wide and expression analysis of protein phosphatase $2 \mathrm{C}$ in rice and Arabidopsis. BMC Genom. 2008, 9, 550-561. [CrossRef] [PubMed]

42. Cohen, P. The structure and regulation of protein phosphatases. Ann. Rev. Biochem. 1989, 58, 453-459. [CrossRef] [PubMed]

43. Sanders, P.M.; Lee, P.Y.; Biesgen, C.; Boone, J.D.; Beals, T.P.; Weiler, E.W.; Goldberg, R.B. The arabidopsis DELAYED DEHISCENCE1 gene encodes an enzyme in the jasmonic acid synthesis pathway. Plant Cell 2000, 12, 1041-1047. [CrossRef] [PubMed]

44. Xing, Y.; Chen, W.; Jia, W.; Zhang, J. Mitogen-activated protein kinase kinase 5 (MKK5)-mediated signalling cascade regulates expression of iron superoxide dismutase gene in Arabidopsis under salinity stress. J. Exp. Bot. 2015, 66, 5971-5978. [CrossRef] [PubMed]

45. Novo-Uzal, E.; Gutiérrez, J.; Martínez-Cortés, T.; Pomar, F. Molecular cloning of two novel peroxidases and their response to salt stress and salicylic acid in the living fossil Ginkgo biloba. Ann. Bot. 2014, 114, 923-929. [CrossRef]

46. Chen, S.; Vaghchhipawala, Z.; Li, W.; Asard, H.; Dickman, M.B. Tomato phospholipid hydroperoxide glutathione peroxidase inhibits cell death induced by Bax and oxidative stresses in yeast and plants. Plant Physiol. 2004, 135, 1630-1641. [CrossRef] [PubMed]

47. Jain, P.; Bhatla, S.C. Signaling role of phospholipid hydroperoxide glutathione peroxidase (PHGPX) accompanying sensing of $\mathrm{NaCl}$ stress in etiolated sunflower seedling cotyledons. Plant Signal. Behav. 2014, 9, 977746-977747. [CrossRef] 